\title{
Hanford Environmental Dose Reconstruction Project
}

Monthly Report

July 1990
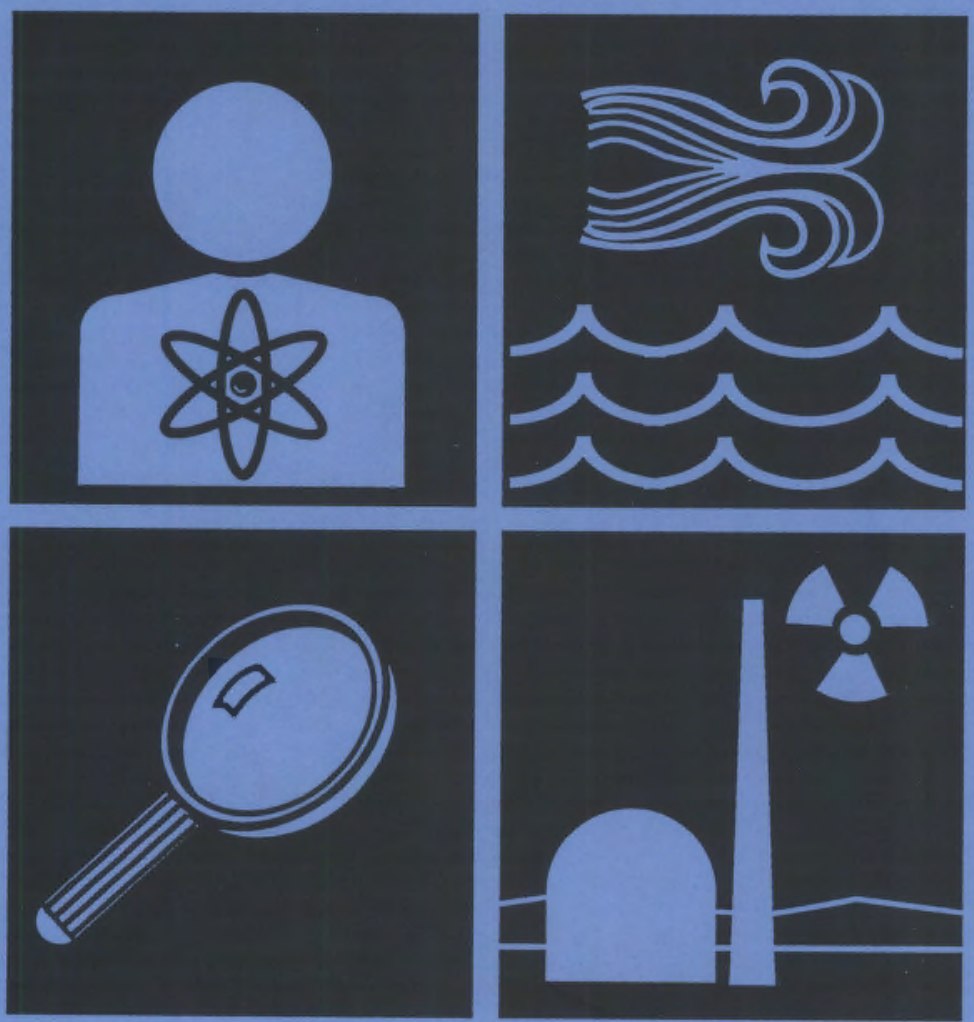

Prepared for the Technical Steering Panel

\%० Battelle 


\title{
DISCLAIMER
}

This report was prepared under the direction of the HANFORD ENVIRONMENTAL DOSE RECONSTRUCTION PROJECT Technical Steering Panel by Battelle Memorial Institute's Pacific Northwest Laboratories operating the Pacific Northwest Laboratory for the U.S. Department of Energy (DOE). While funding for the work was provided by DOE, the work is not under DOE direction or control. The views and opinions of the authors expressed in this document do not necessarily reflect those of the United States Government or any agency thereof. Reference herein to any specific commercial product, process or service by trade name, trademark, manufacturer or otherwise does not necessarily constitute or imply its endorsement, recommendation or favoring by the U.S. Government or any agency thereof, nor by Battelle Memorial Institute.

\author{
Printed in the United States of America \\ Available from \\ National Technical Information Service \\ United States Department of Commerce \\ 5285 Port Royal Rosd \\ Springfield, Virginia 22161 \\ NTIS Price Codes \\ Microfiche A01 \\ Printed Copy
}

$\begin{array}{cc}\begin{array}{c}\text { Pages } \\ 001-025\end{array} & \begin{array}{c}\text { Podes } \\ \text { Cod }\end{array} \\ 026-050 & \text { A02 } \\ 051-075 & \text { A03 } \\ 076-100 & \text { A04 } \\ 101-125 & \text { A05 } \\ 126-150 & \text { A06 } \\ 151-175 & \text { A07 } \\ 176-200 & \text { A06 } \\ 201-225 & \text { A09 } \\ 226-250 & \text { A10 } \\ 251-275 & \text { A11 } \\ 276-300 & \text { A12 } \\ & \text { A13 }\end{array}$


HANFORD ENVIRONMENTAL DOSE RECONSTRUCTION PROJECT

Monthly Report

July 1990

Prepared for the Technical Steering Panel

Pacific Northwest Laboratory

Richland, Washington 99352 
PNL-6450-33 HEDR

UC-707

\section{HANFORD ENVIRONMENTAL DOSE RECONSTRUCTION PROJECT}

Compiled By: M M turch

S. M. Finch, Project Coordinator

Hanford Environmental Dose Reconstruction Project

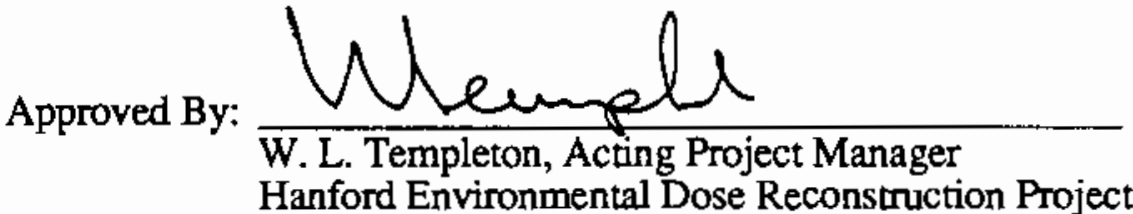

Approved By: $\frac{\text { W. L. Templeton, Manager }}{\text { Office of Hanford Environment }}$ 
:

, 


\section{Preface}

This monthly report summarizes the technical progress and project status for the Hanford Environmental Dose Reconstruction (HEDR) Project being conducted at the Pacific Northwest Laboratory (PNL) (a) under the direction of a Technical Steering Panel (TSP). The TSP is composed of experts in numerous technical fields related to this project and represents the interests of the public. The U.S. Department of Energy (DOE) funds the project.

Figure 1 shows the PNL organizational structure of the HEDR Project. Table 1 shows the status of PNL work to comply with directives issued by the TSP.

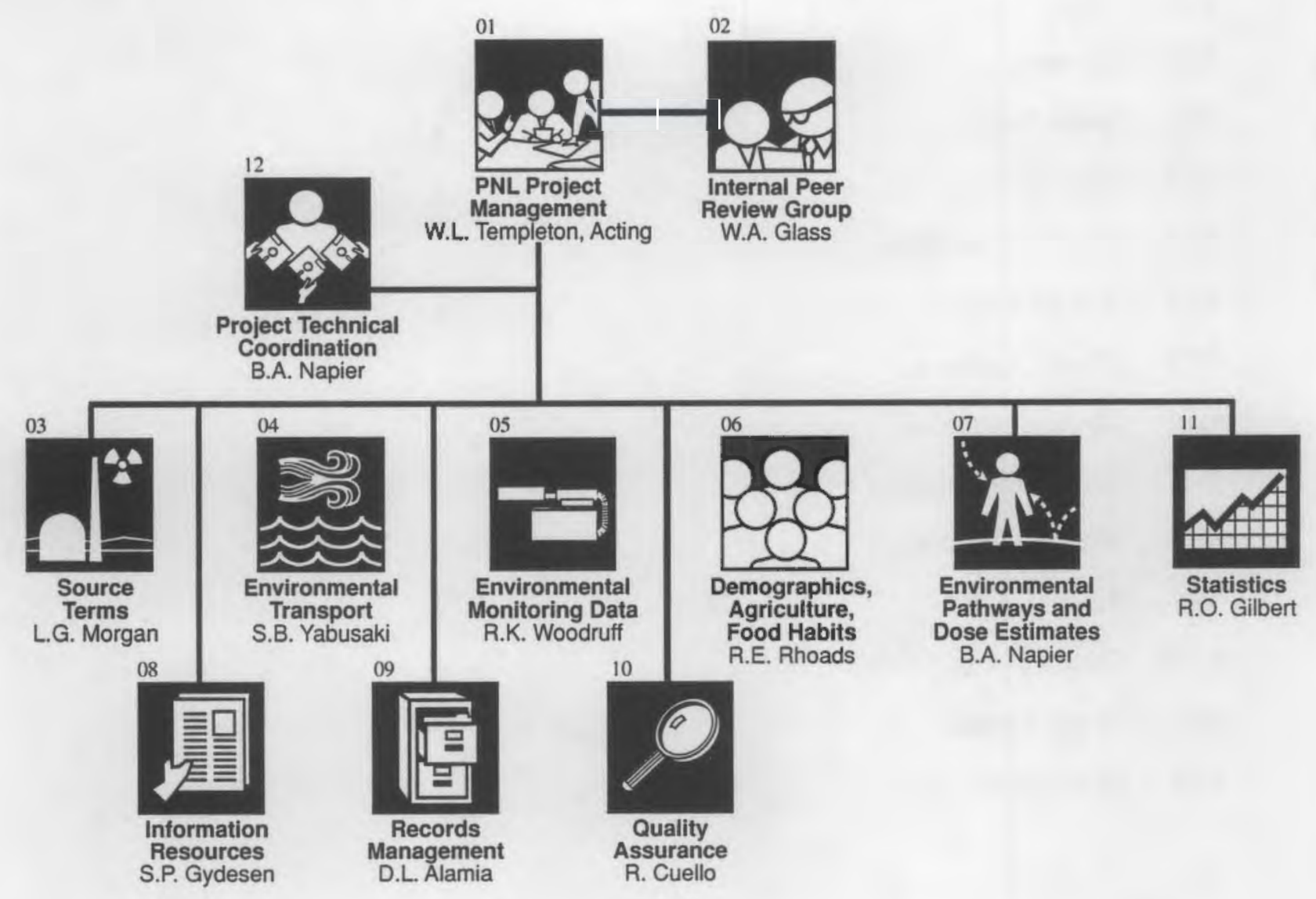

FIGURE 1. Organizational Structure of the Hanford Environmental Dose Reconstruction Project

(a)Battelle Memorial Institute operates the Pacific Northwest Laboratory. 
TABLE 1. Status of Directives(a)

\section{Complete Ongoing Phase I Phase II}

88-1 - (a) Proposals

(b) Source Terms

88-2 Vegetation

88-3 Status Reports

88-4 Ground Water

88-5 Maps

88-6 Resumes

89-1 Indian Tribes

89-2 Bioassay Data

89-3 Document Handling

89-4 Reactor Purging

89-5 Phased Approach

89-6 Meeting Materials

89-7 Tech Communication

89-8 Phase II Planning

89-9 Project QA Plan

89-10 Contracts with Tribes

90-1 Project Direction

90-2 Dose Cut-Off Limit $\mathbf{x}$

$\mathbf{x}$

$\mathbf{x}$

$\mathbf{x}$

$\mathbf{x}$

x $\mathbf{x}$

$\mathbf{x}$

X

X

$\mathbf{x}$

X

X

x

X

X

X

$\mathbf{x}$

x

X

x

X

X

(a) Note: For simplicity, TSP directives are identified here using only key words. The complete directives are available from the TSP. 


\section{Executive Summary}

The objective of the Hanford Environmental Dose Reconstruction Project is to estimate the radiation doses that populations could have received from nuclear operations at Hanford since 1944. The project is being managed and conducted by the Pacific Northwest Laboratory (PNL) under the direction of an independent Technical Steering Panel (TSP).

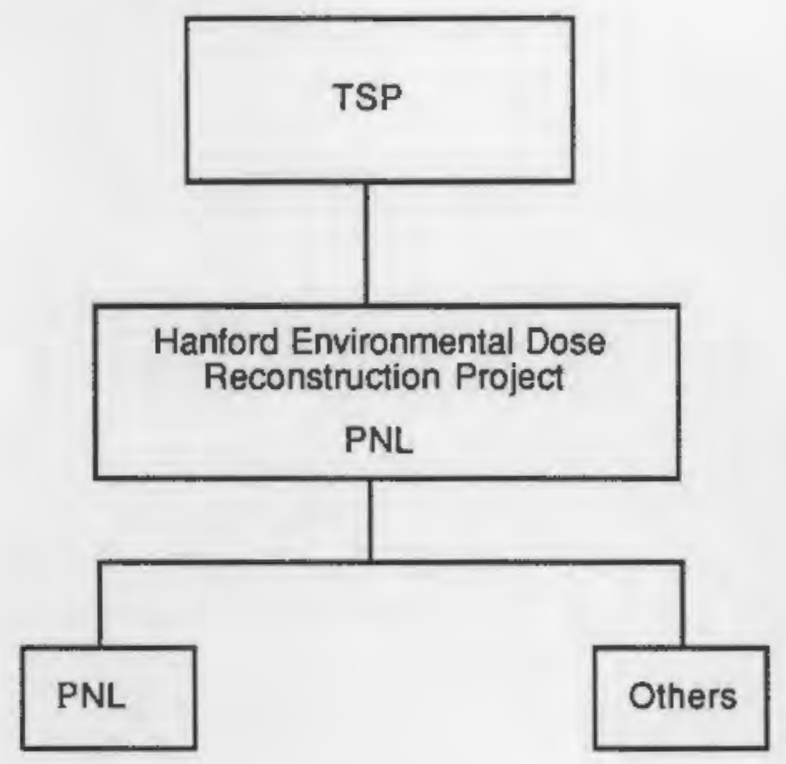

The TSP consists of experts in environmental pathways, epidemiology, surface-water transport, ground-water transport, statistics, demography, agriculture, meteorology, nuclear engineering, radiation dosimetry, and cultural anthropology. Included are appointed technical members representing the states of Oregon and Washington, cultural and technical experts nominated by the regional Native American tribes, and an individual representing the public.

The project is divided into the following technical tasks. These tasks correspond to the path radionuclides followed, from release to impact on humans (dose estimates):

- Source Terms

- Environmental Transport

- Environmental Monitoring Data

- Demographics, Agriculture, Food Habits

- Environmental Pathways and Dose Estimates.
The Source Terms Task develops estimates of radioactive emissions from Hanford facilities since 1944. These estimates are based on historical measurements and production information.

The Environmental Transport Task reconstructs the movement of radioactive materials from the areas of release to populations. Movement via the atmosphere, surface water (Columbia River), and ground water are studied.

The Environmental Monitoring Data Task assembles, evaluates, and reports historical environmental monitoring data. A major effort of this task is to separate Hanford as a source of radionuclide concentrations in the environment from concentrations caused by natural sources and nuclear testing fallout.

The Demographics, Agriculture, Food Habits Task develops the data needed to identify the populations that could have been affected by the releases. Population and demographic information are developed for the general population within the study area. This information will also be developed for several special population groups, including Native American tribes in the study area, Amy personnel who were stationed at Hanford, Hanford construction workers, and migrant farm workers.

In addition to population and demographic data, the food and water sources and consumption patterns for these populations are estimated because they provide a primary pathway for the intake of radionuclides. Historical dairy farming practices and milk distribution systems are studied because milk is a significant pathway for iodine131 to enter the human body. Cows could have eaten vegetation contaminated with this radionuclide.

The Environmental Pathways and Dose Estimates Task uses the information produced by the other tasks to estimate the radiation doses populations could have received from Hanford radiation.

Project reports and references used in the reports are made available to the public in a public reading room. Project progress is documented in this monthly report, which is available to the public. 



\section{Management Summary}

\section{Progress}

Figure 2 shows the status of project milestone activities. The following major activities were conducted by HEDR staff in July 1990:

- submitted the three draft Phase I reports-Summary, Air Pathway, and Columbia River Pathway--to the TSP for review and public distribution

- helped TSP members prepare for the July 12 public meeting in which they announced the preliminary results of the draft Phase I reports

- attended several TSP subcommittee meetings in Richland on July 12-13

- verified the accuracy of previously published iodine-131 data transcribed from one laboratory record book to another

- placed Work Order No. 1 (developing a Work Plan) with the Umatilla Indian Reservation

- completed preliminary documentation of the dose calculation computer code; wrote draft user's manuals; placed the computer code under configuration management

- conducted a staff debriefing of the results of the PNL Quality Assurance (QA) Audit of the HEDR Project

- submitted to the TSP for review the report, "Initial Communication Survey Results for the HEDR Project"

- $\quad$ presented the invited paper, "Statistical Aspects of the Hanford Environmental Dose Reconstruction Project," at the American Statistical Association Conference on Radiation and Health, Copper Mountain, Colorado, July $8-12,1990$. The proceedings of the conference will be published in Radiation Research

- submitted the abstract, "Atmospheric Modeling for Dose Reconstruction at Hanford" to the American Nuclear Society for its 1990 Winter Meeting
- met with staff of the Fred Hutchinson Cancer Research Center to discuss coordination with the Hanford Thyroid Disease Study

- provided the DOE-RL Public Reading Room with 25 documents of potential interest/use in the HEDR Project.

\section{Major Issues and Action Taken}

None.

\section{Planned Work for Subsequent Months}

Work planned for subsequent months includes the following:

- continue working with the TSP to plan Phase II activities

- begin writing a report describing the methodology and sources of information used to calculated the quantities of iodine-131 released to the atmosphere during 1944-1947

- develop guidelines that set forth the minimum contents of the Phase II QA plan

- write a report on the results of the computer simulations conducted to quantify the effects of the modular construction of the Phase I Monte Carlo air-pathway dose model on the distributions of dose estimates

- develop statistical procedures for use with the recently acquired Geographical Information System.

\section{Budget Status}

Figures 2 and 3 show the budget status of the HEDR Project and TSP activities, respectively.

Projected HEDR expenditures through July 1990 were $\$ 2,520 \mathrm{~K}$. Actual expenditures through July 1990 were $\$ 2,517 \mathrm{~K}$. 


\section{Variance Explanation}

The current cumulative variance between planned and actual costs is $0 \%$. An additional $\$ 285 \mathrm{~K}$ of funding was received during July, as anticipated and noted in the May monthly report. The planned expenditures were modified to reflect the receipt of the additional funding.

\section{Capital Status}

Capital equipment funding of $\$ 141 \mathrm{~K}$ was approved and allocated for the purchase of a Geographic Information System. The computers and software were delivered and set up in April. 
FIGURE 2. Project Summary Report - Hanford Environmental Dose Reconstruction Project

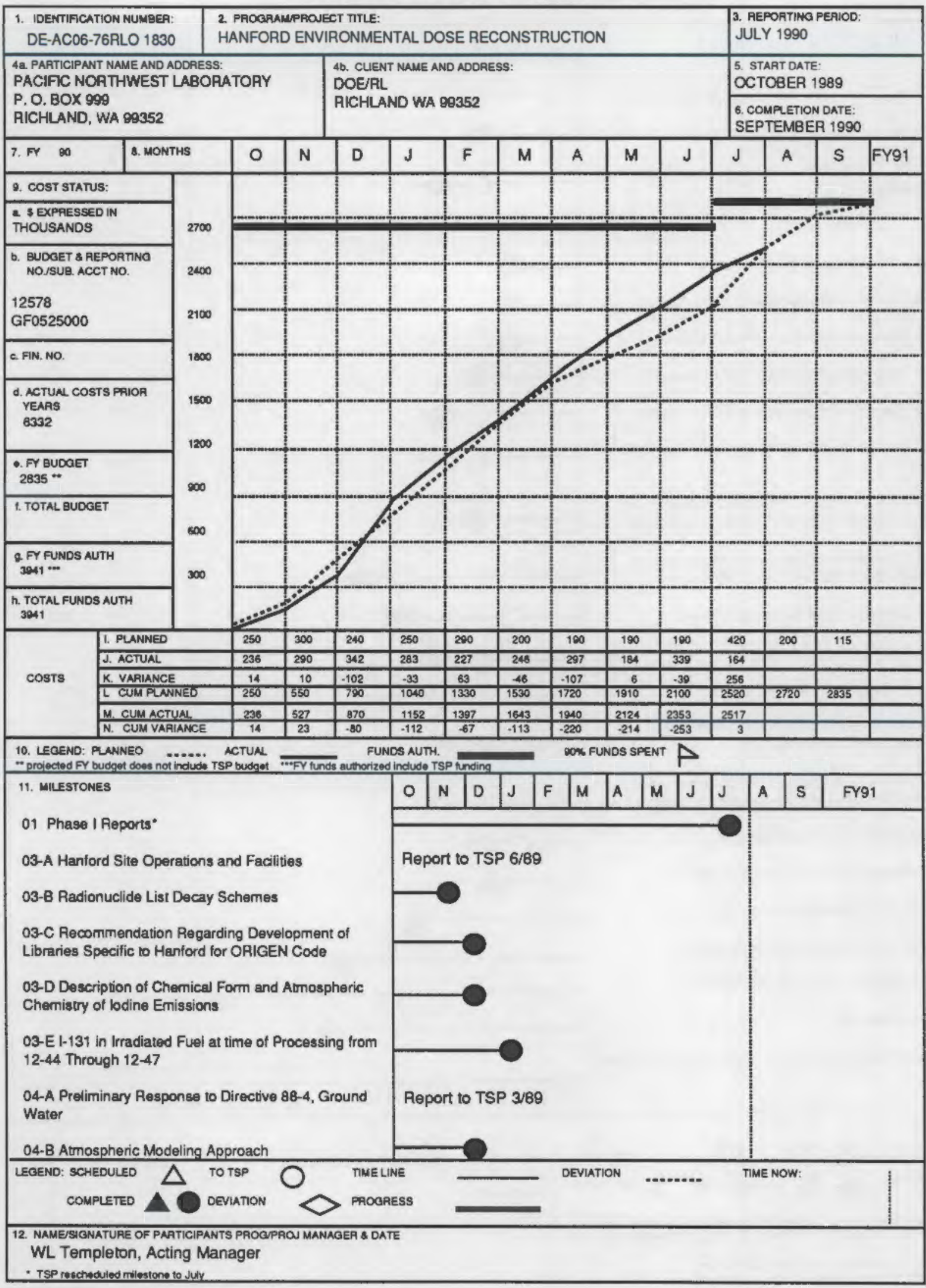


FIGURE 2. Project Summary Report - Hanford Environmental Dose Reconstruction Project (Contd.)

11. MILESTONES, continued

04-C Phase I Atmospheric Model and Input Data

04-D Phase I Atmospheric Model Results

04-E Phase I Surtace Water Conceptual Model and

Calculations

O5-A 1-131 Sample Vegetation Data

05-B Final Piver and Sediment Monitoring Data

05-C Measured River Fish Concentrations

06-A Review of Literature on Public Interaction

O6-B Phase I Demo Analysis for HEDR Project

06-C Phese I Food Consurmption Estimates for HEDR

Project

06-D Initial Description of the Milk Production and Distribution System for the HEDR Phase I Study Area

06-E Stralegies and Approaches for Interactions Between the Public and the HEDR Project

07-A Computer Code Design Specilications

07-B Thyroid Data Summary

07-C Radionuclide Transfer Factors

12-A Define Age Groups, Utanization and Subpopulation Categories

12-B Feasibility of Using 1-129 Concentrations in Human Tissue to Estimate Radiation Dose from I-131

12-C L.ist Dominant Radionuclides

TSP Meeting Planning and Preparation

TSP Meeting Planning and Preparation

TSP Meeting Planning and Proparation

TSP Meeting Planning and Preparation

Phase II Planning

Phase II Planning w/TSP in response to Directive $60-1$

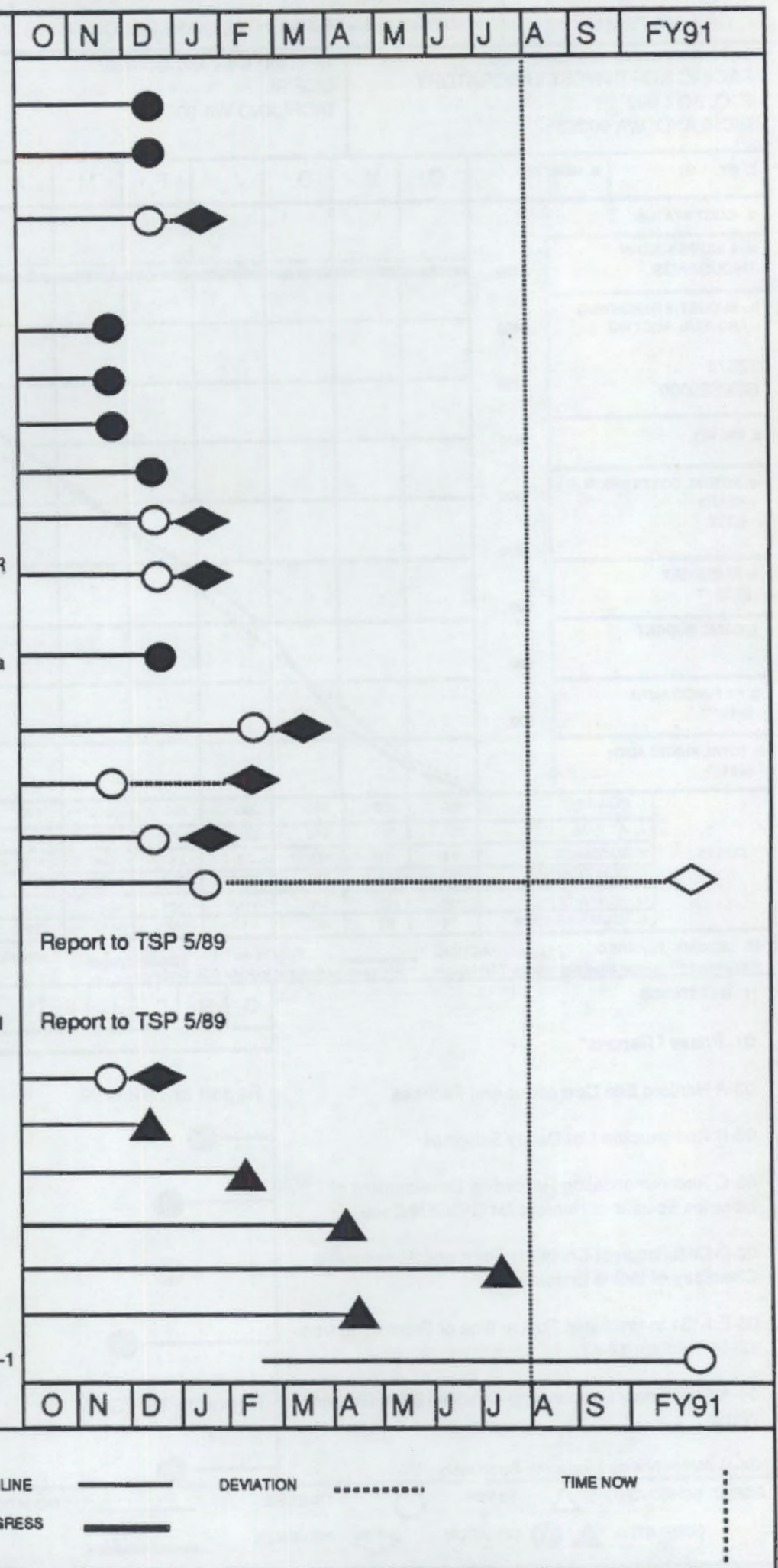

\section{LEGEND:}

SCHEDULED

COMPLETED

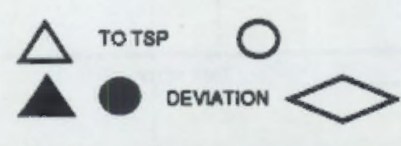

TIME UNE

PAOGRESS

12. NAMESSIGNATURE OF PARTICIPANTS PAOG/PROS MANAGER \& DATE

WL Templeton, Acting Manager 
FIGURE 3. Project Summary Report - Technical Steering Panel

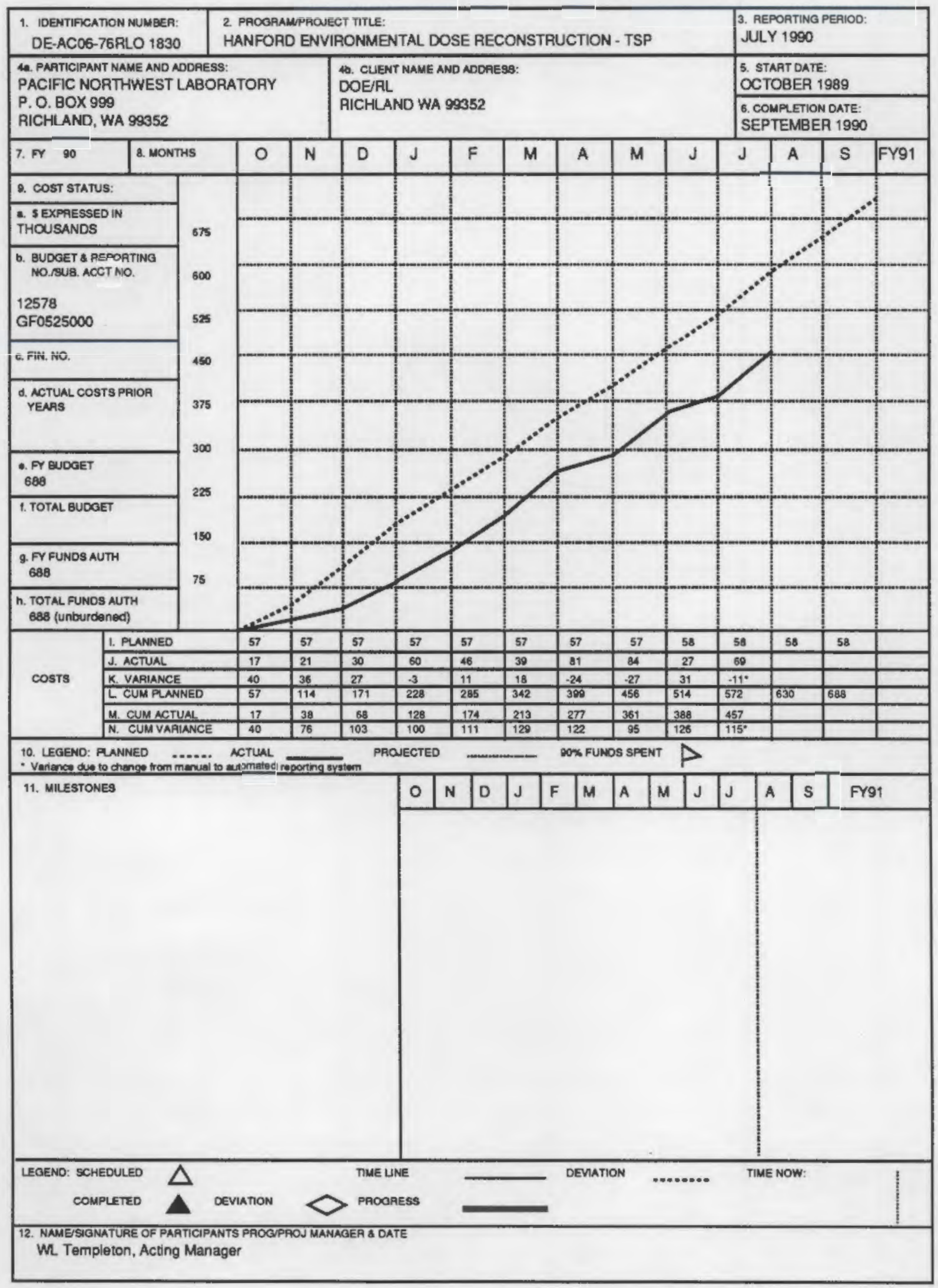





\section{Contents}

Preface. . . . . . . . . . . . . . . . . .

Executive Summary. . . . . . . . . . . . . . . . . vii

Management Summary. . . . . . . . . . . . . . . . . . .

Source Terms . . . . . . . . . . . . . . . . . . . . .

Environmental Transport. . . . . . . . . . . . . . . . . . . . 3

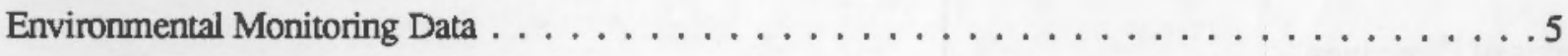

Demographics, Agriculture, Food Habits. . . . . . . . . . . . . . . 7

Environmental Pathways and Dose Estimates $\ldots \ldots \ldots \ldots \ldots \ldots \ldots \ldots$

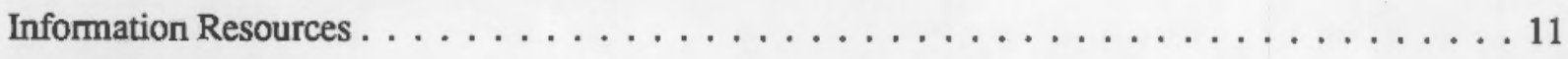

Records Management. . . . . . . . . . . . . . . . . . . . 13

Quality Assurance . . . . . . . . . . . . . . . . . . . 15

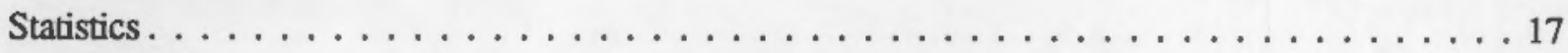

Project Technical Coordination . . . . . . . . . . . . . . . . . . 19

Appendix A - Hanford-Site-Originated Documents of Potential Interest/Use to the HEDR

Project - Placed in the DOE-RL Public Reading Room during July 1990 . . . . . A.1

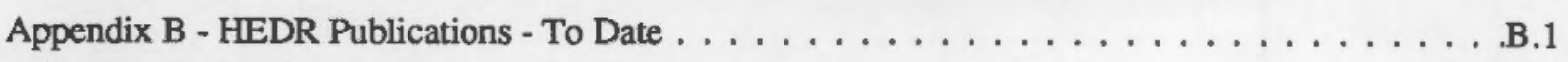

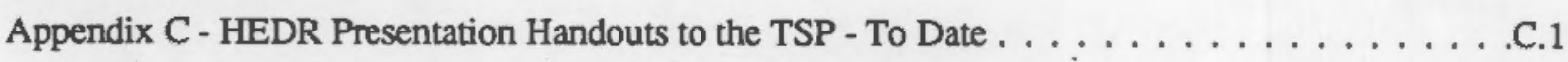

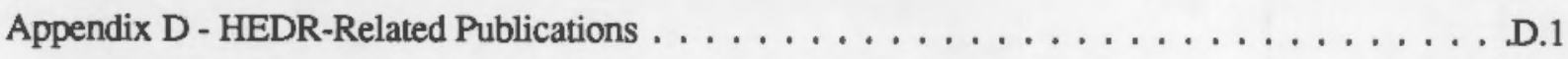

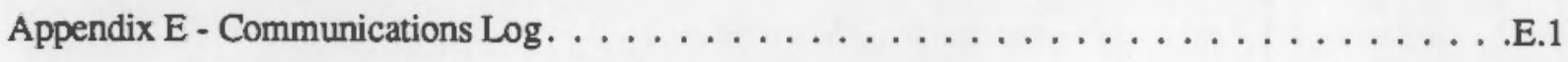




\section{Figures}

1 Organizational Structure of the Hanford Environmental Dose Reconstruction Project . . . . . . . v

2 Project Summary Report - Hanford Environmental Dose Reconstruction Project . . . . . . . . . xi

3 Project Summary Report - Technical Steering Panel . . . . . . . . . . . . . . xiii

\section{Tables}

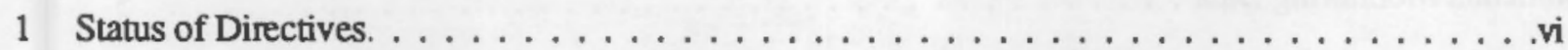




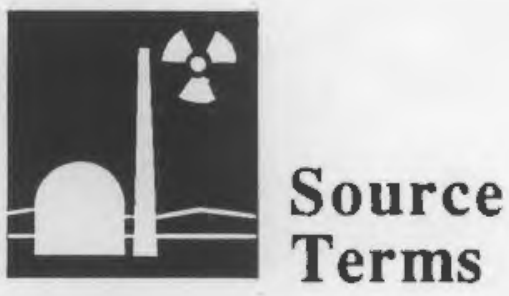

\section{Objective}

Source terms are the amount and type of radioactive materials released to the environment. Members of the Source Terms Task develop estimates of radioactive emissions since 1944 from Hanford facilities based on historical measurements and production information. Source term estimates are used by Environmental Transport Task members to reconstruct the concentrations of radionuclides in the environment.

Uncertainty in calculated and measured data can result from many factors. Uncertainties in measured emissions may result from early measurement techniques. For calculated emissions, uncertainties may result from the differences in published variables that are used to perform calculations. By comparing the uncertainty in the available data, Source Term Task staff determine the most accurate method for developing source terms. For time periods where measured values do not exist, source terms are calculated from available information. The proposed methods and results of this task are reviewed, evaluated, and approved by the TSP.

\section{Progress}

Activities for this reporting period included the following:

- met with a TSP member and J. D. Anderson (Westinghouse Hanford Company) to verify that data transcribed from one laboratory record book to another contained no transcription errors. The data were used to calculate iodine-131 releases for the draft Phase I reports.

\section{Major Problem Areas and Action Taken}

None.

\section{Planned Work for Subsequent Months}

Work planned for the subsequent months includes the following:

- begin preparing a summary report describing the methodology and sources of information used to calculate the quantities of iodine-131 released to the atmosphere during 1944-1947.

The following activity is proposed for subsequent months and will be performed if approved by the TSP:

- determine the need to conduct sensitivity calculations using ORIGEN2.(a)

\footnotetext{
(a)A. G. Croff. 1980. "ORIGEN2: A Revised and Updated Version of ORIGEN." Transactions of the American Nuclear Society, Volume 34, pp 349-350, June 1980.
} 



\section{Environmental Transport}

\section{Objective}

Members of the Environmental Transport Task reconstruct the movement of radioactive materials (the source term information) from the areas of release to the environment. Radionuclide movement via the atmosphere, Columbia River, and ground water are studied.

To track releases to the atmosphere from Hanford Site operations, meteorological data are needed, including wind speed, wind direction, and other data that affect the dispersion of the releases. Mathematical models are applied to these meteorological data and the source term data to calculate concentrations of radionuclides in the air and on the ground. The TSP reviews, evaluates, and provides direction conceming the proposed models.

Reconstruction of the transport of radionuclides in the Columbia River is based primarily on historical studies of the Columbia River and its tributaries. Computer models are used to reconstruct radionuclide concentrations in the river for time periods when previously published data are limited or unavailable.

The movement of radionuclides in the ground water is reconstructed initially by using ground-water monitoring data to estimate the contribution to the Columbia River exposure pathway. Modeling will be used where previously published data are lacking.

\section{Progress}

Activities for this reporting period included the following:

- attended a briefing on the June Atmospheric Transport and Diffusion Workshop at the TSP Environmental Transport Subcommittee meeting in July. The Subcommittee stated that the puff model approach used in the atmospheric transport model for dose calculation is reasonable, but recommended that several changes to the model be considered.

- discussed potential Phase II activities with the Environmental Transport Subcommittee of the TSP
- submitted the abstract, "Atmospheric Modeling for Dose Reconstruction at Hanford" to the American Nuclear Society for its 1990 Winter Meeting.

\section{Major Problem Areas and Action Taken}

None.

\section{Planned Work for Subsequent Months}

The following activities are proposed for subsequent months and will be performed if approved by the TSP:
- atmospheric pathway
- sensitivity studies for computer-model development


- surface-water pathway

- conceptual model investigation

- comparison of mass balance routing calculations to Phase I monitoring data

- sensitivity study of Phase I results. 


\section{Environmental Monitoring Data}

\section{Objective}

Members of the Environmental Monitoring Data Task assemble, evaluate, and summarize key historical measurements of the concentrations of radionuclides in the environment around the Hanford Site.

Radionuclide concentrations have been measured at various times in air, drinking water, foods, fish, the Columbia River, soil, and in other materials. These measurements are evaluated to estimate their accuracies and then used by Environmental Pathways and Dose Estimates Task staff to estimate radiation doses and by Environmental Transport Task staff to calibrate computer models. Methods to attain this objective are proposed to the TSP for review, evaluation, and approval.

\section{Progress}

Activities this reporting period included the following:

None.

\section{Major Problem Areas and Action Taken}

None.

\section{Planned Work for Subsequent Months}

The following activities are proposed for subsequent months and will be performed if approved by the TSP:

- examine the magnitude of the effect of Phase I assumptions on 1945-1947 measured concentrations of iodine-131 on vegetation
- evaluate sensitivity of dose calculations to accuracy and precision in previously published radionuclide measurements in fish and water from the Columbia River

- determine necessary extent of the database on radionuclides in terrestrial media

- determine the suitability of "green run" air data for use in later project phases. 



\section{Demographics, Agriculture, Food Habits}

\section{Objective}

Task members develop the demographic, food consumption, and food production information needed to estimate doses.

Demographic information is developed for the general population and for several special population groups that are not adequately represented by the U.S. Census, including Native American tribes, Army personnel stationed at Hanford, some Hanford construction workers, and migrant workers.

In addition to demographic data, the sources and quantities of food and water consumed must be estimated, because food and water provide pathways for the intake of radionuclides.

Airbome radionuclides from the plant stacks may have been deposited on fruits and vegetables.

Consumption of these foods provided a pathway for radionuclide transport to humans. The exposure pathways are studied. In addition, milk produced from cows represents a significant food pathway for iodine-131 if the cows ate vegetation contaminated with radionuclides. Dairy farming practices and milk distribution systems are studied to identify the populations that may have consumed potentially contaminated milk.

Consumption of contaminated fish and shellfish is also a food pathway for exposure to radioactive materials. Estimates of the amount of potentially contaminated fish and shellfish consumed from the Columbia River and ocean bays are developed through an extensive review of numerous past studies.

Treated Columbia River water was used by some community members downstream from Hanford. Drinking this water provided a pathway for exposure to radioactive materials. To estimate the doses from this pathway, it is necessary to know the communities using the water, the amount of water withdrawn, the treatment process, the travel time through the system, and the amount of water consumed. Irrigation water use downstream from Hanford is also studied because radioaclive materials in the river water could have been deposited on crops consumed by people or animals. Recreational users of the river also could have been exposed to radiation from the river and shoreline. Food and lifestyle habits of Native Americans that differentiate them from the general population will also be considered. Methods to collect data and to estimate population densities and food consumption have been proposed to the TSP for review, evaluation, and approval. 


\section{Progress}

Activities for this reporting period included the following:

- placed Work Order No. 1 (developing a Work Plan) with the Umatilla Indian Reservation

- presented a method to collect food consumption data from Native American tribes at a working session during the July 12-13 TSP meeting

- submitted to the TSP for review the report, "Initial Communication Survey Results for the HEDR Project." The results are from a Washington State University omnibus survey of Washington State residents. Results will be used in TSP communications planning and evaluation.
Major Problem Areas and Action Taken

None.

\section{Planned Work for Subsequent}

Months

Work planned for subsequent months includes the following:

- continue preparation for Phase II activities. 


\section{Environmental Pathways and Dose Estimates}

\section{Objective}

Task members use calculated and measured concentrations of radionuclides provided by members of the Environmental Transport Task and the Environmental Monitoring Data Task to calculate doses to populations, typical individuals, and specific individuals. These calculations include doses via direct transfer of radionuclides from concentrations in air and water to people (via breathing, drinking, immersion, etc.). The calculations also include doses from radionuclide concentrations in air and water transferred through environmental pathways, such as soil, plants, animals, and fish, to people. All significant decisions on exposure models and input parameters are presented to the TSP for review, evaluation, and approval.

\section{Progress}

Activities for this reporting period included the following:

- completed preliminary documentation for the Phase I dose calculation computer code; wrote draft user manuals for the code; placed the code under configuration management.

\section{Major Problem Areas and Action Taken}

None.

\section{Planned Work for Subsequent Months}

The following activities are proposed for subsequent months and will be perfomed if approved by the TSP:

- perform sensitivity analysis calculations

- evaluate sensitivity of dose estimates to changes in model structure

- evaluate the need for age-dependent dose factors

- calculate estimated doses for Native American tribes. 
- 


\section{Information Resources}

\section{Objective}

Members of the Information Resources Task work with the other task members to meet information needs, including ensuring that all data referenced in the reports are publicly available and establishing a microcomputer-based tracking system for ready retrieval of historical information.

\section{Progress}

Activities for this reporting period included the following:

- added new citations to the tracking system that now numbers more than 3,500

- provided the DOE-RL Public Reading Room with 25 documents of potential interest/use in the HEDR Project. The majority of these reports are relatively large and address daily or monthly activities primarily during the period 1944-1947. A title listing of these reports is attached in Appendix A

- filled information requests from the TSP and HEDR task members.

\section{Major Problem Areas and Action Taken}

None.

\section{Planned Work for Subsequent Months}

Planned work for subsequent months includes the following:

- make necessary arrangements to determine the existence or non-existence of Hanford Siteoriginated documents that were transferred to the corporate headquarters of General Electric during the years 1946 through 1964

- continue to add input to the information resources tracking data base

- continue to provide documents to the DOE-RL Public Reading Room in an orderly, timely fashion

- develop a list of Hanford-originated raw data logs/notes of potential interest/use to the HEDR Project

- continue to identify and collect significant documents that address silver reactor capabilities, performance, and incidents

- watch for information that may explain in detail, and support data in, "green run" document HW-17381 DEL

- identify significant documents that address fuel element failures that occurred in now decommissioned Hanford Production Reactors

- continue to identify and collect documents and/or data of potential interest/use to the HEDR Project that address activities during the years from reactor startup through 1949. 



\section{Records Management}

\section{Objective}

Members of the Records Management Task provide storage and control of completed project records, maintain an automated inventory of all project documentation, and provide a reference service to project staff and the TSP.

\section{Progress}

Activities for this reporting period included the following:

- received and processed project records

- transferred three record packages to the DOERL Public Reading Room.

\section{Major Problem Areas and Action}

Taken

None.

\section{Planned Work for Subsequent Months}

Work planned for subsequent months includes the following:

- continue processing incoming project records

- continue transferring processed project records to the DOE-RL Public Reading Room. 



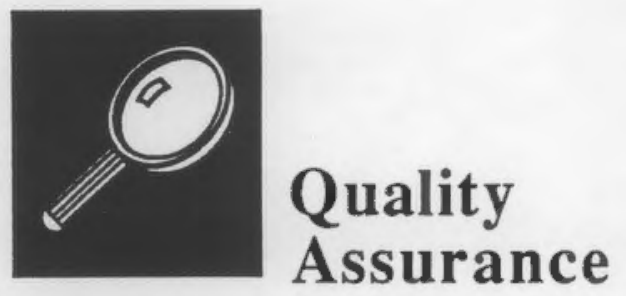

\section{Objective}

The objective of this task is to ensure continuous quality assurance (QA) support and coordination with all project tasks. This objective is met through the identification and documentation of QA requirements in the form of a QA Plan and periodic monitoring of project activities during the life of the project to ensure compliance with these requirements.

\section{Progress}

Activities for this reporting period included the following:

- conducted a staff debriefing of the results of the PNL QA Audit of the HEDR Project

- continued working on expanding the existing QA plan to include project-specific data quality objectives that will be included as part of Phase II planning.

\section{Major Problem Areas and Action} Taken

None.

\section{Planned Work for Subsequent Months}

Work planned for subsequent months includes the following:

- issue remaining HEDR procedures: HEDRTP-3, "HEDR Documentation of Critical Decisions" and "HEDR-TP-4, "HEDR Data Quality Objectives"

- develop guidelines that set forth the minimum contents of the Phase II QA plan. 



\section{Statistics}

\section{Objective}

Task members provide statistical support to members of technical tasks and develop and apply sensitivity and uncertainty analyses. Sensitivity analyses will be used to identify parameters with the greatest influence on dose estimates. Using sensitivity analyses results, project staff can focus resources where the benefit in terms of accurate dose estimates is greatest. Uncertainty analyses enable task leaders to determine the extent to which the accuracy and precision of the dose estimates are influenced by accuracy and precision in the input parameters.

\section{Progress}

Activities this reporting period included the following:

- conducted computer simulations to determine confidence levels associated with preliminary dose distributions for reference individuals in specified census divisions in the Phase I study area

- completed quantifying the effects of the modular construction of the Phase I Monte Carlo air-pathway dose model on the distributions of dose estimates

- began QA documentation of the statistical analysis procedures and results that were developed/obtained for the Phase I reports

- presented the invited paper "Statistical Aspects of the Hanford Environmental Dose Reconstruction Project" at the American Statistical Association Conference on Radiation and Health, Copper Mountain, Colorado, July 8-12, 1990 . The proceedings of the conference will be published in Radiation Research

- continued documenting the multiplicative lognormal dose reconstruction code development.

\section{Major Problem Areas and Action Taken}

None.

\section{Planned Work for Subsequent Months}

Work planned for subsequent months includes the following:

- continue to integrate statistical ideas and methods into restructuring the Phase I dose estimation code as needed

- write a report on the results of the computer simulations conducted to quantify the effects of the modular construction of the Phase I Monte Carlo air-pathway dose model on the distributions of dose estimates

- revise for publication in Radiation Research the paper, "Statistical Aspects of the Hanford Environmental Dose Reconstruction Project"

- finish QA documentation of the statistical analysis procedures and results that were developed/obtained for the Phase I report

- conduct statistical analyses and summarizations of whole-body-counter data on schoolchildren and adults in the RichlandPasco-Kennewick area that were obtained in 
the 1960 s to help validate the HEDR dose model. Conduct similar analyses for grossbeta thyroid counts of Hanford workers in the mid-1940s
- develop statistical procedures for use with the recently acquired Geographic Information System. 


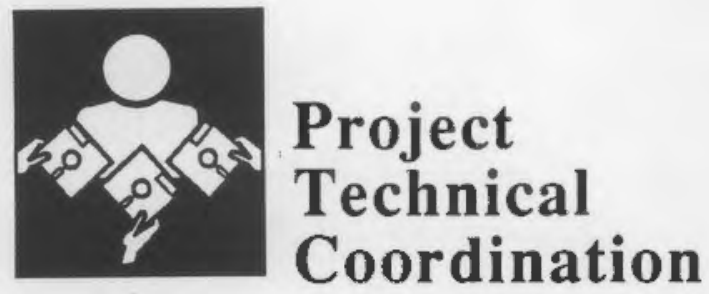

\section{Objective}

The objective of the Project Technical Coordination Task is to provide a general technical overview of the project to ensure that appropriate information is generated from the technical tasks for performing the final dose calculations.

\section{Progress}

Activities this reporting period included the following:

- helped brief TSP members on the contents and interpretation of the draft Phase I reports

- met with staff of the Fred Hutchinson Cancer Research Center July 13 to discuss coordination with the Hanford Thyroid Disease Study.

\section{Major Problem Areas and Action} Taken

None.

\section{Planned Work for Subsequent Months}

The following activities are proposed for subsequent months and will be performed if approved by the TSP:

- continue coordinating efforts with thyroid disease study personnel

- continue defining the overall structure of the needed HEDR database and the type of data needed for smooth project integration

- work with the Intemational Atomic Energy Agency Coordinated Research Program on Validation of Model Predictions (VAMP) to validate portions of the HEDR model and to obtain independent estimates of certain doses

- supervise training and implementation of the HEDR Geographic Information System. 



\section{Appendix A}

\section{Hanford-Site-Originated Documents}

of Potential Interest/Use to the HEDR Project Placed in the DOE-RL Public Reading Room During July 1990 


\section{Appendix A}

\section{Hanford-Site-Originated Documents of Potential Interest/Use to the HEDR Project - Placed in the DOE/RL Public Reading Room During July 1990}

HAN-45763

HAN-45804

HW-3-2224

HW-7-1649-DEL

HW-7-1793-DEL

HW-7-1981-DEL

HW-7-2361-DEL

HW-7-2548-DEL

HW-7-2706-DEL

HW-7-2957-DEL

HW-7-3378-DEL

HW-7-3751-DEL

HW-7-5944-DEL

HW-11814

HW-21177

HW-39966

HW-66891

HW-68751-REV

HW-69723

HW-69988-REV2
200 Area Daily Logs 1-1-47 to 6-30-47. 166 p.

$6 / 30 / 47$

100 Areas Monthly Reports for $1947.170 \mathrm{p}$.

$12 / 31 / 47$

100-B Unit Purge, April 12, 1945. 9 p.

$4 / 16 / 45$

Hanford Engineer Works Monthly Report April 1945. 96 p.

$5 / 14 / 45$

Hanford Engineer Works Monthly Report May 1945. 106 p.

$6 / 16 / 45$

Hanford Engineer Works Monthly Report June 1945. 105 p.

$7 / 14 / 45$

Hanford Engineer Works Monthly Report August 1945. $100 \mathrm{p}$.

$9 / 18 / 45$

Hanford Engineer Works Monthly Report September 1945. $99 \mathrm{p}$.

$10 / 17 / 45$

$11 / 7 / 45$

88 p.

Hanford Engineer Works Monthly Report November 1945.

$93 \mathrm{p}$.

Hanford Engineer Works Monthly Report January 1946.

$97 \mathrm{p}$.

$12 / 11 / 45$

$2 / 8 / 46$

Hanford Engineer Works Monthly Report March 1946.86 p.

$4 / 5 / 46$

Hanford Engineer Works Monthly Report February 1947. $153 \mathrm{p}$.

$3 / 14 / 47$

Ruptured Slug - Tube 0569-B. 7 p.

$12 / 17 / 48$

Determination of Radioiodine in Organic Material. $4 \mathrm{p}$.

$5 / 16 / 51$

Iodine-131 Gamma Scintillation Monitor. 8 p.

$11 / 14 / 55$

Automatic Columbia River Monitoring Station 21 p.

$10 / 6 / 60$

Control Limits for the Concentration of Radioactive Materials in Aqueous and Gaseous Effluents from the Plutonium Recycle

$4 / 17 / 61$

Test Reactor. 9 p.

Existing and Proposed Studies at HAPO Relating to the Columbia River. $17 \mathrm{p}$.

$5 / 24 / 61$

Design Limits for Radioactive Waste Disposal from the Fuels Recycle Pilot Plant. 7 p. 
HW-72042

Improved Facilities for the Removal of Iodine-131 from

$4 / 2 / 62$

HW-76772 PUREX Process Vent Off-Gas. 29 p.

HW-78196

Radiological Aspects of Hanford Land Utilization. 20 p.

$2 / 26 / 63$

N Reactor Secondary Loop Contamination. $31 \mathrm{p}$.

$8 / 23 / 63$

NUREG/CR-3344

MESOI Version 2.0: An Interactive Mesoscale Lagrangian

(PNL-4753)

Puff Dispersion Model with Deposition and Decay. 223 p.

$11 / 30 / 83$ 
Appendix B

HEDR Publications - To Date 
Appendix B

HEDR Publications - To Date

\begin{tabular}{cccc} 
Title & Author & $\begin{array}{c}\text { Date } \\
\text { Issued }\end{array}$ & $\begin{array}{c}\text { Publication } \\
\text { No. }\end{array}$ \\
\hline
\end{tabular}

Hanford Environmental Dose Reconstruclion Project Monthly Report

Draft Sumnary Report

Draft Air Pathway Repor

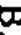

- Draft Water Pathway Report

Initial Survey Results for the HEDR

Project

QA Audit Report of the HEDR Project-

Data Traceability, A-90-15

A Preliminary Examination of AudienceRelated Communicalions Issues: Hanford

Environmental Dose Reconstruction Project

MESOILT2, A Lagrangian Trajeclory

Climatological Dispersion Model

Population Estimates for Phase I

Estimates of Food Consumption
HEDR Project

Office

HEDR Stalf

HEDR Staff

HEDR Staff

$7 / 90$

PNL-7411 HEDR

Available from TSP

Beck, DM

$7 / 90$

Pratt, RC

$7 / 90$

PNL-7423 HEDR

Results of WSU omnibus survey

of WA State residents

PNL-7428 HEDR

Holmes, CW

$4 / 90$

PNL-7231 HEDR

Ramsdell, JV

$4 / 90$

PNL-7340 HEDR

Beck, DM

$2 / 90$

PNL-7263 HEDR

Callaway

$2 / 90$

PNL-7260 HEDR
Periodic report; TSP

approval nol

necessary

Released

$7 / 12 / 90$ by the

TSP (draft)

Released

$7 / 12 / 90$ by the

TSP (draft)

Released

$7 / 12 / 90$ by the

TSP (draft)

To TSP for review 7/90

To TSP for review $7 / 90$

PNL addressing

TSP commen

PNL addressing

TSP comments

PNL addressing

TSP comments

PNL addressing

TSP comments 
HEDR Publications - To Date

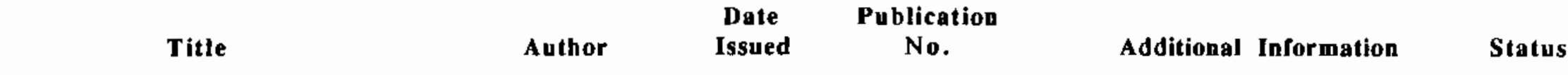

Soil Ingestion by Dairy Cattle

Darwin, RF

$2 / 90$

NL-SA-17918

HEDR

Computational Model Design Specification

Napier, BA

$2 / 90$

PNL-7274 HEDR

for Phase I of the Hanford Environmental

Dose Reconstruction Project

Estimates of Columbia River Radionuclide

Concentrations: Data for Phase I Dose

Richmond, MC;

$1 / 90$

Walters, WH

Ikenberry, $\mathbf{R}$

$1 / 90$

PNL-7254 HEDR

Evaluation of Thyroid Radioactivity

Measurement Dala From Hanford

Workers, 1944-1946

I-131 in Irradiated Fuel at Time of Processing Morgan, LG

from December 1944 Through December 1947

Work Plan for the Hanford Environmental Haerer, HA

Dose Reconstruction Project

$1 / 90$

$12 / 89$

Uncerlainties in Source Term Calculations

Generated by the ORIGEN2 Computer Code

for Hanford Production Reaciors

Selection of Dominant Radionuclides for

Phase I of the HEDR Project

Atmospheric Transpor and Dispersion

Modeling for the Hanford Environmental

Dose Reconstruction Project
Heeb, CM

Napier, BA

Ramsdell, JV
$12 / 89$

PNL-7223 HEDR

$12 / 89$
PNL-7253 HEDR

PNL-6696 HEDR

REV 1

PNL-7248 HEDR

dressing

TSP comments

PNL addressing

TSP comments

PNL addressing

TSP comments

TSP approved; published 12/89

PNL addressing

TSP comments

PNL addressing

TSP comments

PNL addressing

TSP comments 
HEDR Publications - To Date

\begin{tabular}{|c|c|c|c|c|c|}
\hline Title & Author & $\begin{array}{l}\text { Date } \\
\text { Issued }\end{array}$ & $\begin{array}{l}\text { Publication } \\
\text { No. }\end{array}$ & Additional Information & Status \\
\hline $\begin{array}{l}\text { Atmospheric Transport Modeling and Input } \\
\text { Data for Phase I of the Hanford } \\
\text { Environmental Dose Reconstruction Project }\end{array}$ & $\begin{array}{l}\text { Ramsdell, JV; } \\
\text { Burk, KW }\end{array}$ & $12 / 89$ & PNL-7199 HEDR & & $\begin{array}{l}\text { PNL addressing } \\
\text { TSP comments }\end{array}$ \\
\hline $\begin{array}{l}\text { Fission-Product Iodine During Early Hanford- } \\
\text { Site Operations: ILs Production and Behavior } \\
\text { During Fuel Processing, Off-Gas Treatment, } \\
\text { and Release o the Atmosphere }\end{array}$ & Burger, LL & $12 / 89$ & PNL-7210 HEDR & & $\begin{array}{l}\text { PNL addressing } \\
\text { TSP comments }\end{array}$ \\
\hline $\begin{array}{l}\text { The Hanford Environmental Dose } \\
\text { Reconstruction Project: Background } \\
\text { Information }\end{array}$ & Byram, SJ & $12 / 89$ & $\begin{array}{l}\text { PNL-SA-17658 } \\
\text { HEDR }\end{array}$ & For use with focus groups & $\begin{array}{l}\text { TSP approval not } \\
\text { rexpired }\end{array}$ \\
\hline $\begin{array}{l}\text { Summary of Literature Review of Risk } \\
\text { Communication }\end{array}$ & Bугаm, SJ & $12 / 89$ & PNL-7226 HEDR & & $\begin{array}{l}\text { PNL addressing } \\
\text { TSP comments }\end{array}$ \\
\hline $\begin{array}{l}\text { Milk Cow Feed Intake and Milk Producion } \\
\text { and Distribution Estimates for Phase I }\end{array}$ & Beck, DM & $12 / 89$ & PNL-7227 HEDR & & $\begin{array}{l}\text { PNL addressing } \\
\text { TSP comments }\end{array}$ \\
\hline $\begin{array}{l}\text { Preliminary Summaries for Vegetation, River } \\
\text { and Drinking Water and Fish Radionuclide } \\
\text { Concentration Data (DRAFT) }\end{array}$ & Woodnuff, RK & $11 / 89$ & $\begin{array}{l}\text { PNL-SA-17641 } \\
\text { HEDR }\end{array}$ & & $\begin{array}{l}\text { To TSP for review } \\
12 / 89\end{array}$ \\
\hline $\begin{array}{l}\text { Radionuclide Sources and Radioactive Decay } \\
\text { Figures Pertinent to the HEDR Project }\end{array}$ & Heeb, CM & $10 / 89$ & PNL-7177 HEDR & & $\begin{array}{l}\text { PNL addressing } \\
\text { TSP comments }\end{array}$ \\
\hline $\begin{array}{l}\text { Estimations of Traditional Native American } \\
\text { Diets in the Columbia Plateau }\end{array}$ & $\begin{array}{l}\text { Hunn, ES; } \\
\text { Bnuneau, CL }\end{array}$ & $8 / 89$ & PNL-SA-17296 & & Reviewed by tribes \\
\hline $\begin{array}{l}\text { Summary of Workshop on Milk Production } \\
\text { and Disuribution, November 30, 1988- } \\
\text { HEDR Project }\end{array}$ & Beck, DM, et al. & $7 / 89$ & PNL-6975 HEDR & & To TSP $8 / 89$ \\
\hline $\begin{array}{l}\text { A History of Major Hanford Operations } \\
\text { Involving Radioactive Material }\end{array}$ & $\begin{array}{l}\text { Ballinger, MY; } \\
\text { Hall, RA }\end{array}$ & $6 / 89$ & PNL-6964 HEDR & & $\begin{array}{l}\text { TSP reviewed; PNL } \\
\text { addressing comments }\end{array}$ \\
\hline
\end{tabular}


HEDR Publications - To Date

\begin{tabular}{|c|c|c|c|c|c|}
\hline Title & Author & $\begin{array}{l}\text { Date } \\
\text { Issued }\end{array}$ & $\begin{array}{c}\text { Publication } \\
\text { No. }\end{array}$ & Additional Information & Status \\
\hline $\begin{array}{l}\text { Feasibility of Using } 1291 \text { Concentrations in } \\
\text { Human Tissue to Estimate Radiation } \\
\text { Dose from } 131 \text { I }\end{array}$ & McComack, WD & $4 / 89$ & PNL-6889 HEDR & & $\begin{array}{l}\text { TSP approved 9/89; } \\
\text { published } 1989\end{array}$ \\
\hline $\begin{array}{l}\text { Summary Report of HEDR Workshop on } \\
\text { Sensitivity and Uncertainty Analysis }\end{array}$ & $\begin{array}{l}\text { Sagar, B; } \\
\text { Liebelrau, AM }\end{array}$ & $3 / 89$ & $\begin{array}{l}\text { PNL-SA-16804 } \\
\text { HEDR }\end{array}$ & $\begin{array}{l}\text { Summary of workshop held } \\
\text { Janшary 16-18, } 1989\end{array}$ & $\begin{array}{l}\text { Sent to Till 3/89-no } \\
\text { wriluen response } \\
\text { provided to PNL }\end{array}$ \\
\hline $\begin{array}{l}\text { Response to TSP Direclive 88-4, Ground- } \\
\text { Water Contamination Data }\end{array}$ & Freshley, MD & $3 / 89$ & PNL-6847 HEDR & & $\begin{array}{l}\text { TSP received } 3 / 89 ; \text { no } \\
\text { written response } \\
\text { provided to PNL }\end{array}$ \\
\hline $\begin{array}{l}\text { Demographic, Agricultural, Food Consump- } \\
\text { tion, and Lifestyle Research for the Hanford } \\
\text { Environmental Dose Reconstruction Project }\end{array}$ & Beck, DM, et al. & $2 / 89$ & PNL-6834 HEDR & $\begin{array}{l}\text { Incorporates earlier TSP } \\
\text { comments }\end{array}$ & $\begin{array}{l}\text { TSP received 3/89; no } \\
\text { written response } \\
\text { provided to PNL }\end{array}$ \\
\hline $\begin{array}{l}\text { Proposed Approach for Developing } \\
\text { Information on Population Food } \\
\text { Consumption and Lifestyles of } \\
\text { Native Americans in the HEDR } \\
\text { Study Area }\end{array}$ & $\begin{array}{l}\text { Rhoads, RE; } \\
\text { Bruneau, CL }\end{array}$ & $1 / 89$ & PNL-6803 HEDR & Working document & $\begin{array}{l}\text { TSP comments were } \\
\text { incorporated into } \\
\text { PNL-6834 HEDR }\end{array}$ \\
\hline $\begin{array}{l}\text { Hanford Environmental Dose } \\
\text { Reconstruction }\end{array}$ & Bruneau, $\mathrm{CL}$. & $1 / 89$ & $\begin{array}{l}\text { PNWD-1323 } \\
\text { HEDR }\end{array}$ & $\begin{array}{l}\text { Informational brochure used in PNL's } \\
\text { work with Tribes }\end{array}$ & $\begin{array}{l}\text { TSP approval not } \\
\text { required }\end{array}$ \\
\hline Hanford Environmental Dose Reconstruction & Haeser, HA & $9 / 88$ & PNL-6696 HEDR & Superseded by new work plan & TSP approved \\
\hline
\end{tabular}




\section{Appendix C}

\section{HEDR Presentation Handouts to the TSP - To Date}


Appendix $\mathrm{C}$

HEDR Presentation Handouts to the TSP - to Date

\begin{tabular}{|c|c|c|c|c|}
\hline Title & Author & $\begin{array}{l}\text { Date } \\
\text { Issued }\end{array}$ & $\begin{array}{l}\text { Publication } \\
\text { No. }\end{array}$ & Additional Information \\
\hline $\begin{array}{l}\text { Hanford Enviranmental Dose Reconstruction } \\
\text { Project - Phase I Report }\end{array}$ & Haerer, HA & $5 / 0$ & $\begin{array}{l}\text { PNL-18304 S } \\
\text { HEDR }\end{array}$ & $\begin{array}{l}\text { Presented at the workshop, "Public Health Aspects of Hanford } \\
\text { Heatth Studies, A Workshop for State, Local, and Tribal Health } \\
\text { Officials," June 6, } 1990\end{array}$ \\
\hline $\begin{array}{l}\text { Detailed Example Calculations for HEDR, } \\
\text { Phase I }\end{array}$ & Napier, BA & $2 / 90$ & $\begin{array}{l}\text { PNL-SA-17913 } \\
\text { HEDR }\end{array}$ & Presented at the TSP mIg. Feb 15-17, 1990, Richland, WA \\
\hline Communications Directive & Rhoads, RE & $2 / 90$ & $\begin{array}{l}\text { PNL-SA-17903 S } \\
\text { HEDR }\end{array}$ & Presented at the TSP mtg, Feb 15-17, 1990, Richland, WA \\
\hline HEDR Project Report to the TSP & Haerer, HA & $2 / 90$ & $\begin{array}{l}\text { PNL-SA-27904S } \\
\text { HEDR }\end{array}$ & Presented at the TSP mtg, Feb 15-17, 1990, Richland, WA \\
\hline $\begin{array}{l}\text { Hanford Environmental Dose Reconstruction } \\
\text { Project }\end{array}$ & Haerer, HA & $12 / 89$ & $\begin{array}{l}\text { PNL-SA-17661S } \\
\text { HEDR }\end{array}$ & Presented at the TSP mtg, December 11-13, 1989, Richland, WA \\
\hline Communicalions Directive & Rhoads, RE & $12 / 89$ & $\begin{array}{l}\text { PNL-SA-17653 S } \\
\text { HEDR }\end{array}$ & Presented at the TSP mtg, December 11-13, 1989, Richland, WA \\
\hline $\begin{array}{l}\text { Preliminary Evaluation of Thyroid Bioassay } \\
\text { Data from Hanford Workers, 1944-1946 }\end{array}$ & $\begin{array}{l}\text { Ikenberry, T; } \\
\text { Napier, BA }\end{array}$ & $12 / 89$ & $\begin{array}{l}\text { PNL-SA-17670 S } \\
\text { HEDR }\end{array}$ & Presented at the TSP mtg, December 11-13, 1989, Richland, WA \\
\hline Overview of Project Model - Air Palhway & Napier, BA & $12 / 89$ & $\begin{array}{l}\text { PNL-SA-17673 } \\
\text { HEDR }\end{array}$ & Presented at the TSP mtg, December 11-13, 1989, Richland, WA \\
\hline $\begin{array}{l}\text { Source Terms - Air Pathway } \\
\text { Source Terms - Surface-Water Pathway }\end{array}$ & Morgan, LG & $12 / 89$ & $\begin{array}{l}\text { PNL-SA-17657 } \\
\text { HEDR }\end{array}$ & Presented at the TSP mtg, December 11-13, 1989, Richland, WA \\
\hline Aumospheric Transport Model & Freshley, MD & $12 / 89$ & $\begin{array}{l}\text { PNL-SA-17662 S } \\
\text { HEDR }\end{array}$ & Presented at the TSP mtg, December 11-13, 1989, Richland, WA \\
\hline $\begin{array}{l}\text { Environmental Monitoring Data: } \\
\text { Vegetation, 1945-1947 }\end{array}$ & Woodruff, RK & $12 / 89$ & $\begin{array}{l}\text { PNL-SA-17671 } \\
\text { HEDR }\end{array}$ & Presented at the TSP mtg, December 11-13, 1989, Richland, WA \\
\hline
\end{tabular}


HEDR Presentation Handouts to the TSP - to Date

\begin{tabular}{|c|c|c|c|c|}
\hline Title & Author & $\begin{array}{l}\text { Date } \\
\text { Issued }\end{array}$ & $\begin{array}{l}\text { Publication } \\
\text { No. }\end{array}$ & Additional Information \\
\hline $\begin{array}{l}\text { Preliminary Calculated and Measured Concen- } \\
\text { trations of Iodine-131 in Vegetation for } \\
\text { Phase I }\end{array}$ & Napier, BA & $12 / 89$ & $\begin{array}{l}\text { PNL-SA-17674 } \\
\text { HEDR }\end{array}$ & Presented at the TSP mtg, December 11-13, 1989, Richland, WA \\
\hline Milk Production and Distribution & Beck, DM & $12 / 89$ & $\begin{array}{l}\text { PNL-SA-17649 S } \\
\text { HEDR }\end{array}$ & Presented at the TSP mtg, December 11-13, 1989, Richland, WA \\
\hline $\begin{array}{l}\text { Overview of Project Model - Surface-Water } \\
\text { Pathway }\end{array}$ & Napier, BA & $12 / 89$ & $\begin{array}{l}\text { PNL-SA-17672 } \\
\text { HEDR }\end{array}$ & Presented at the TSP mig, December 11-13, 1989, Richland, WA \\
\hline Surface-Water Palhway & Freshley, MD & $12 / 89$ & $\begin{array}{l}\text { PNL-SA-17660 S } \\
\text { HEDR }\end{array}$ & Presented at the TSP mtg, December 11-13, 1989, Richland, WA \\
\hline $\begin{array}{l}\text { Environmental Measurements - } \\
\text { Columbia River }\end{array}$ & $\begin{array}{l}\text { Poston, TM; } \\
\text { Dirkes, } \mathbf{R}\end{array}$ & $12 / 89$ & $\begin{array}{l}\text { PNL-17669 } \\
\text { HEDR }\end{array}$ & Presented at the TSP mtg, December 11-13, 1989, Richland, WA \\
\hline Phase II Planning & Haerer, HA & $12 / 89$ & $\begin{array}{l}\text { PNL-17661 S } \\
\text { HEDR }\end{array}$ & Presented at the TSP mtg, December 11-13, 1989, Richland, WA \\
\hline $\begin{array}{l}\text { Discussion with TSP Subcommituee on } \\
\text { Communication Stralegy }\end{array}$ & Rhoads, RE & $10 / 89$ & $\begin{array}{l}\text { PNL-SA-17475 } \\
\text { HEDR }\end{array}$ & $\begin{array}{l}\text { Presented at the TSP Subcommittee meeting on Communication } \\
\text { Strategy, October 5, 1989, Portand, OR }\end{array}$ \\
\hline Surface Water Exposure Pathways & $\begin{array}{l}\text { Napier, BA; } \\
\text { Poston, TM }\end{array}$ & $10 / 89$ & $\begin{array}{l}\text { PNL-SA-17502 S } \\
\text { HEDR }\end{array}$ & $\begin{array}{l}\text { Presented at the TSP meeting, October 12.14, 1989, } \\
\text { Portland, OR }\end{array}$ \\
\hline HEDR Project Report to the TSP & Haerer, HA & $10 / 89$ & $\begin{array}{l}\text { PNL-SA-17501 } \\
\text { HEDR }\end{array}$ & Presented at the TSP mtg, Oct 12-14, 1989, Portland, OR \\
\hline $\begin{array}{l}\text { Methods for Presenting Results to the } \\
\text { Public }\end{array}$ & Rhoads, RE & $8 / 89$ & $\begin{array}{l}\text { PNL-SA-17368 } \\
\text { HEDR }\end{array}$ & Presented at the TSP meeting, September 6, 1989, Porland, OR \\
\hline $\begin{array}{l}\text { HEDR Project Report to the TSP } \\
\text { July } 21,1989\end{array}$ & Hacrer, HA & $7 / 89$ & $\begin{array}{l}\text { PNL-SA-17218 } \\
\text { HEDR }\end{array}$ & Presented at the TSP mtg, July 21, 1989, Richland, WA \\
\hline $\begin{array}{l}\text { Radionuclides Transported by the Columbia } \\
\text { River }\end{array}$ & Freshlcy, MD & $7 / 89$ & $\begin{array}{l}\text { PNL-SA-17235 } \\
\text { HEDR }\end{array}$ & Piesented at the TSP mtg, July 21, 1989, Richland, WA \\
\hline
\end{tabular}




$\begin{array}{lccc}\text { Title } & \text { Date } & \text { Publication } & \\ \text { Author } & \text { Issued } & \text { No. } & \text { Additional Information }\end{array}$

Defining Demographic Categories for

Phase I

HEDR Project Report to the TSP for

May 1989 Public Meeting

Task 6 - Population, Food Consumplion

and Lifestyles

HEDR Native American Population, Food Consumption and Lifestyle Suidy - Data

Requirements

C Hanford Environmental Dose Reconstruclion

i Project - Report to the Technical Steering

Panel

Availability of I-131 Vegetalion Data

Price, KR

Atmospheric Pathway

Ramsdell, JV

Napier, BA;

Beck, DM

Haerer, HA

Rhoads, RE

Bruneau, CL

Haener, HA

HEDR

PNL-SA-16794

$5 / 89$

3/89 PNL-SA-16785

$3 / 89$

$1 / 89$

1/89 PNL-SA-16565

HEDR Demography, Agriculture, and

Lifestyle Research

Aspects of Sensitivity/Uncertainty Analysis in the HEDR Project

HEDR Demography, Agriculture, and Lifestyle Research

Surface Water Transport

Uncerbinty
Beck, DM

Sagar, B.

Beck, DM

Walters, W.
$1 / 89$

$1 / 89$

$1 / 89$

$1 / 89$
PNL-SA-17035

HEDR

PNL-SA-17032 HEDR

HEDR

PNL-SA-16784

HEDR

PNL-SA-16573

HEDR

HEDR

Presentation handout for the TSP mtg, May 18-20, 1989 ,

Toppenish, WA

Presented at the TSP mtg, May 18-20, 1989, Toppenish, WA

Presented at the Native American Workshop, March 14-15, 1989 , Richland, WA

Presented at the Native American Workshop, March 14-15, 1989, Richland, WA

PNL-SA-16568 HEDR

PNL-SA-16571

HEDR

PNL-SA-16568 HEDR

PNL-SA-16572 HEDR
Presented at the TSP meeling, March 17, 1989, Spokane, WA

Presented at HEDR workshop on Sensitivity and Uncertainty

Presented at the HEDR workshop on Sensilivity and Uncertainty Analysis, January 16-18, 1989, Pasco, WA

Presented at the HEDR workshop on Sensilivity and Uncertainty Analysis, January 16-18, 1989, Pasco, WA

Presented at the HEDR Workshop on Sensitivity and Uncertainty Analysis, January 16-18, 1989, Pasco, WA

Presented at the HEDR Workshop on Sensitivity and Uncertainty Analysis, January 16-18, 1989, Pasco, WA

Presented at the HEDR Workshop on Sensitivity and Analysis, January 16-18, 1989, Pasco, WA Analysis, January 16-18, 1989, Pasco, WA 
HEDR Presentation Handouts to the TSP - to Date

\begin{tabular}{|c|c|c|c|c|}
\hline Title & Author & $\begin{array}{l}\text { Date } \\
\text { Issued }\end{array}$ & $\begin{array}{l}\text { Publication } \\
\text { No. }\end{array}$ & Additional Information \\
\hline Source Terms & Morgan, LG & $1 / 89$ & $\begin{array}{l}\text { PNL-SA-16566 } \\
\text { HEDR }\end{array}$ & $\begin{array}{l}\text { Presented at the HEDR Workshop on Sensitivity and Uncertainty } \\
\text { Analysis, January 16-18, 1989, Pasco, WA }\end{array}$ \\
\hline Experience with Gress and Swals & Piepho, MG & $1 / 89$ & $\begin{array}{l}\text { PNL-SA-16567 } \\
\text { HEDR }\end{array}$ & $\begin{array}{l}\text { Presented at the HEDR Workshop on Sensilivity and Uncertainty } \\
\text { Analysis, January 16-18, 1989, Pasco, WA }\end{array}$ \\
\hline Purpose of Workshop & Gilbert, D. & $1 / 89$ & $\begin{array}{l}\text { PNL-SA-16569 } \\
\text { HEDR }\end{array}$ & $\begin{array}{l}\text { Presented at the HEDR Workshop on Sensitivity and Uncertainty } \\
\text { Analysis, January 16-18, 1989, Pasco, WA }\end{array}$ \\
\hline Example of Sensitivity/Uncertainty Analysis & Strenge, DL & $1 / 89$ & $\begin{array}{l}\text { PNL-SA-16570 } \\
\text { HEDR }\end{array}$ & $\begin{array}{l}\text { Presented at the HEDR Workshop on Sensitivity and Uncertainty } \\
\text { Analysis, January 16-18, 1989, Pasco, WA }\end{array}$ \\
\hline $\begin{array}{l}\text { Estimated Quantity of } 1311 \text { Contained in } \\
\text { Irradiated Fuel at Time of Fuel Processing, } \\
\text { CY 1944-1945 }\end{array}$ & $\begin{array}{l}\text { Jackson, PO; } \\
\text { Morgan, LG }\end{array}$ & $11 / 88$ & $\begin{array}{l}\text { PNL-SA-16398 } \\
\text { HEDR }\end{array}$ & $\begin{array}{l}\text { Presented at the TSP mig, November 11-12, 1988, } \\
\text { Olympia, WA }\end{array}$ \\
\hline
\end{tabular}




\section{Appendix D}

\section{HEDR-Related Publications}

Note: This appendix lists publications that present aspects of dose reconstruction in the open scientific literature; TSP approval is not required. 
Appendix D

HEDR-Related Publications

$\begin{array}{ccc}\text { Title } & \text { Date } & \text { Publication } \\ \text { Issued } & \text { No. }\end{array}$

Status

Planned Materials

Demographic Forecasting Using Trends from Beck and Pittinger

Radio Correlation Variables

Demography (journal) or Journal of

Planning for 1990

Reconstrucling Hiswrical Milk Prod/Dist Beck, DM

Rural Society

Joumal of Health Physics

Planning for 1990

Sysiems

Reconstrucling Food consumption Habits:

Callaway, M;

Journal of Health Physics

Planning for 1990

The Backcasting Method

Carr, D.

Bnuneau, CL;

Rhoads, RE

Jounal (not yet desermined)

Planning for 1990

Nalive American Tribes*

Poston, TM

and Sediment

Communicating Radiation Dose Estimates

HEDR Staff

to Affected Populations

Beck, DM;

Reconstrucling Demography of Native

Bruneau, CL

Americans*

Posion, TM

Health Physics Society Mrg,

Planning for 1990

Anaheim, CA

Jounal of the Society for Risk Analysis

Planning for 1990

Journal of Rural Sociology

Planning for 1990

Fish Concentration Ratios

Beck, DM;

Swanson

Spring/91

for Backcasting

\section{Completed Materials}

Atmospheric Modeling for Dose

Ramsdell, V

$7 / 90$

American Nuclear Society

1990 Winter Meeting

Abstract Submitted

$7 / 90$ 
HEDR-Related Publications

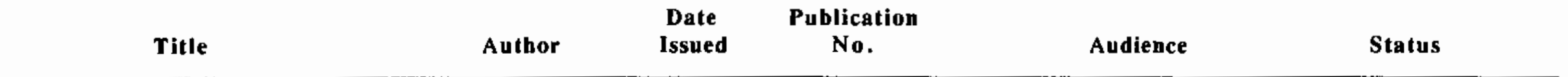

Statislical Aspects of the Hanford

Environmental Dose Reconsiruction

Project

Statistical Aspects of Reconstructing the I-131 Dose to the Thyroid of Individuals Living Near the Hanford Sile in the mid-1940s

Reconstruction of Hanford Vegetaion Monitoring Dala for Dose Reconslruction for 1945-1947

Uncertainty Analysis of the Conversion

i Factor for Historic Iodine-131 Gross Beta Vegelation Measurements

Sensilivity and Uncertainty Analyses for Environmental Dose Reconstruction

The Identification of Terrain-Induced Circulations Using Principal Components

Mathematical and Statistical Aspects of Reconsinucting Doses to Individuals Living Near the Hanford Sile Since the 1940 s

Temporal Variations in Atmospheric Dispersion at Hanford
Gilbert, RO et al.

PNL-SA-18396 S HEDR

Gilbert, RO et al. $\quad 3 / 90$

PNL-SA-17384

American Statistical Association

Presented

Conference on Radiation and Heallh,

$7 / 90$

July 8-12, 1990, Copper Mountain, CO

Workshop: Statistics of Human

Presented 4/90

Radiation Exposure to Ionizing

Radiation, April 2-4, 1990, Oxford, UK

Woodruff, RK;

$1 / 90$

PNL-SA-17760 A HEDR

1990 Health Physics Society Meeting, Presented 6/90 June 24-28, 1990, Anaheim, CA

Strenge, DL et al.

PNL-SA-17713

HEDR

1990 Health Physics Soc. Mtg,

June 24-28, 1990, Anaheim, CA

Presented 6/90

Sagar et al.

$11 / 89$

Skyllingstad, ED

$10 / 89$

PNL-SA-17164

and Schwartz, MN

HEDR

Liebetrau, AM et al. $\quad 10 / 89$

PNL-SA-17498

HEDR

Ramsdell, JV

$9 / 89$

PNL-SA-17375

HEDR
Workshop on uncertainty, Nov 13-16, 1989, Santa Fe, NM

American Meteorological Society

Conference on Probability and

Statislics, October 1-5, 1989

Monterey, CA

SIAM Conference on Applied

Probability in Science and Engineering,

March 5-7, 1990, New Orleans, LA

Hanford Symposium on Health and the

Environment, Oct 16-19, 1989.

Richland, WA
Presented 11/89

Presented 10/89

Presented 3/90

Presented 10/89 
HEDR-Related Publications

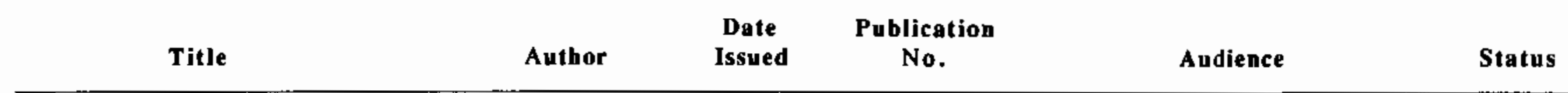

The Hanford Environmental Dose

Reconstruction Project: Overview

The Hanford Environmental Dose

Reconstruction Project: Technical

Approach

The Hanford Environmental Dose

Reconstruction Project: The Role of

Applied Sociology

Potential Applications of Geographical

$\square \quad$ Information Systems for Analyzing Hanford

Environmental Dose Reconstruction Data

Estimating Almospheric Dispersion for Reconslruction of Doses from Hanford

Operations

\author{
Haerer, HA et al.
}

$9 / 89$

PNL-SA-16859

Napier, BA et al.

$9 / 89$

Beck, DM

$4 / 89$

Stephan, JG, et al.

$3 / 89$

Ramsdell, JV

$4 / 88$
HEDR

PNL-SA-16874

HEDR

PNL-SA-16767

HEDR

PNL-SA-15818

HEDR

Hanford Symposium on Health and the

Presented 10/89

Environment, Oct 16-19, 1989

Richland, WA

Hanford Symposium on Health and the Presenticd $10 / 89$

Environment, October 16-19, 1989

Richland, WA

Pacific Sociological Association

Meeling, April 13-16, 1989, Reno, NV

Presented $4 / 89$

PNL-SA-16880

HEDR

Regional Symposium of the HPS

Computer Applications in Health

Presented 3/89

Physics, March 16-17, 1989

Richland, WA

69th Annual Meeting of the Pacific

Division of the American Association

for the Advancement of Science, June 19-

23, 1988, Corvallis, OR

\footnotetext{
*All publications addressing Native American research will be reviewed and approved by the appropriate tribes.
} 

Appendix E

Communications Log 
Appendix E

Communications Log - July 1990

\begin{tabular}{|c|c|c|c|}
\hline Initiated By/Affiliation & Contact/Affiliation & Type & Subject \\
\hline W Templeton/PNL & J Till/TSP, Chairman & Phone & $\begin{array}{l}\text { Ongoing discussions re: HEDR } \\
\text { Project }\end{array}$ \\
\hline W Templeton/PNL & B Shleien/TSP & Phone & $\begin{array}{l}\text { Ongoing discussions re: HEDR } \\
\text { Project }\end{array}$ \\
\hline S Finch/PNL & J Stohr/TSP & Phone & $\begin{array}{l}\text { Ongoing discussions re: meeting } \\
\text { planning }\end{array}$ \\
\hline S Finch/PNL & A Muphy/TSP & Phone & New phone number \\
\hline S Finch/PNL & M Blazek/TSP & Phone & PNL security badge \\
\hline B Schleien/TSP & S Finch/PNL & Phone & HEDR financial data \\
\hline A Fossen/TSP Staff & S Finch/PNL & Phone & Per diem on invoices \\
\hline A McMakin/PNL, & M Blazek/TSP & Phone & Phase I reports \\
\hline A Beers/TSP Staff & A McMakin/PNL & Phone & Phase I reports \\
\hline A McMakin/PNL & A Beers/TSP Staff & Phone & Phase I reports \\
\hline J Daer/PNL & J Stohr/TSP Staff & Phone & Request for TSP resumes \\
\hline J Daer/PNL & J Stohr/TSP Staff & Phone & $\begin{array}{l}\text { Request for } 1989 \text { TSP Annual } \\
\text { Report }\end{array}$ \\
\hline B Cook/Public & L Morgan/PNL & Phone & TSP meetings policy \\
\hline $\begin{array}{l}\text { M Robkin/TSP; } \\
\text { C Heeb/PNL }\end{array}$ & $\mathrm{J}$ Anderson/WHC & Meeting & $1944-1956$ iodine-131 data \\
\hline P Baker/TT Corp & $\begin{array}{l}\text { D Schneider/PNL for } \\
\text { L Morgan/PNL }\end{array}$ & Phone & Releases from $100 \mathrm{H}$ and $100 \mathrm{D}$ areas \\
\hline C Bruneau/PNL & C Carroll/Colville Tribe & Phone & Protocol \\
\hline C Bruneau/PNL & B Burke/Umatilla Tribe & Phone & Protocol \\
\hline $\begin{array}{l}\text { D Powaukee/Nez Perce } \\
\text { Tribe }\end{array}$ & C Bruneau/PNL & Phone & 7/12/90 TSP "working session" \\
\hline C Bruneau/PNL & $\begin{array}{l}\text { D Saluskin/Yakima } \\
\text { Nation }\end{array}$ & Phone & Protocol \\
\hline C Bruneau/PNL & $\begin{array}{l}\text { M Queahpama/Warm } \\
\text { Springs Tribe }\end{array}$ & Phone & $\begin{array}{l}7 / 12 / 90 \text { TSP "working session" and } \\
\text { contract progress }\end{array}$ \\
\hline
\end{tabular}

E. 1 
Communications Log - July 1990

\begin{tabular}{|c|c|c|c|}
\hline Initiated By/Affiliation & Contact/Affiliation & Type & Subject \\
\hline $\begin{array}{l}\text { M Cardwell/Kalispel } \\
\text { Tribe }\end{array}$ & C Bruneau/PNL & Phone & TSP meeting \\
\hline $\begin{array}{l}\text { D Barr/Coeur d'Alene } \\
\text { Tribe }\end{array}$ & C Bruneau/PNL & Phone & Data collection working session \\
\hline C Bruneau/PNL & $\begin{array}{l}\text { M Queahpama/Warm } \\
\text { Springs Tribe }\end{array}$ & Phone & HEDR contract \\
\hline $\begin{array}{l}\text { N Morin/Colorado Dept } \\
\text { of Health }\end{array}$ & S Finch/PNL & Phone & Monthly report distribution \\
\hline J Thomas/HEAL & S Gydesen/PNL & Phone & $\begin{array}{l}\text { Two-person review for } \\
\text { declassification }\end{array}$ \\
\hline N Germond/TSP & S Gydesen/PNL & Phone & Declassification \\
\hline $\begin{array}{l}\text { C Burgess/General } \\
\text { Electric }\end{array}$ & S Gydesen/PNL & Phone & $\begin{array}{l}\text { Hanford-Site-originated reports held } \\
\text { by GE }\end{array}$ \\
\hline
\end{tabular}




\section{Distribution}

No. of

Copies

\section{OFFSITE}

18 Technical Steering Panel

D. S. Barth

University of Nevada

4505 Maryland Parkway

Las Vegas, NV 89154

W. A. Bishop

2503 Wedgewood Coun SE

Olympia, WA 98501

M. L. Blazek

Oregon Department of Energy

625 Marion Street N.E.

Salem, OR 97303

G. G. Caldwell

Director

Tulsa City-County Health Dept

4616 East 15 th Street

Tulsa, OK 74112

S. N. Davis

Dept. of Hydrology \& Water Resources

Bldg. 11

University of Arizona

Tucson, AZ 85721

N. J. Germond

224 Iron Mountain Blvd.

Lake Ozwego, OR 97034

P. C. Klingeman

Civil Engineering Dept.

Oregon State University

Corvallis, OR 97331-2302
No. of

Copies

\author{
K. J. Kopecky \\ Fred Hutchinson Cancer \\ Research Center \\ 1124 Columbia Street \\ Seattle, WA 98104 \\ R. L. Morrill \\ Dept. of Geography \\ DP-10 \\ University of Washington \\ Seattle, WA 98195
}
A. H. Murphy
Depts. of Atmospheric Sciences and Statistics
Strand Agricultural Hall Rm. 331
Oregon State University
Corvallis, OR 97331

V. Nguyen

133 1st Ave. N.

Minneapolis, MN 55401

D. W. Price

Agricultural Economics

Hulbert Hall Room 211

Washington State University

Pullman, WA 99164-6210

M. A. Robkin

Radiological Sciences SB-75

University of Washington

Seattle, WA 98195

G. S. Roessler

Rt. 1, Box 139H

Elysian, MN 56028

Distr. 1 
No. of

Copies

B. Shleien 2421 Homestead Drive

Silver Springs, MD 20902

A. P. Slickpoo, Sr.

P. O. Box 331

809 Nez Perce Lane

Kamiah, ID 83536

J. E. Till

Rt. 2 Box 122

Neeses, SC 29107

D. E. Walker, Jr. c/o P. Arroyo 2041 Walnut St.

Boulder, CO 80302

\section{Bastin, NE-471}

Department of Energy

Room F-416

Germantown, MD 20545

W. Black, EM-321

Department of Energy

Room A-222

Germantown, MD 20545

H. Burgess

General Electric Nuclear Energy

175 Curtner Ave.

Mail Code 822

San Jose, CA 95125

T. Conner

801 Monte Sano Ave. C-2

Augusta, GA 30904

S. Convis, MA-295

Department of Energy

Forrestal Bldg. Room 7E-054

1000 Independence Ave.

Washington, D.C. 20585
No. of

Copies

L. Duffy, S-1

Department of Energy

Forrestal Bldg. Room 7B-118

1000 Independence Ave.

Washington, D.C. 20585

A. Fingeret, GC-22

Department of Energy

Forrestal Bldg. Room 6H-087

1000 Independence Ave.

Washington, D.C. 20585

J. V. Flett

Spokane Business Council

P.O. Box 100

Wellpinit, WA 99040

K. Gebbie, Secretary

Washington Dept of Health

MS ET-21

Olympia, WA 98504

B. Goldsmith, ER-73

Department of Energy

Room E-222

Germantown, MD 20545

H. A. Haerer

NUS Corporation

c/o Battelle-Northwest

P.O. Box 999

Richland, WA 99352

A. P. Hull

Safety \& Environmental

Protection Division

Bldg. 535A

Brookhaven National Laboratory

Upton, NY 11973

L. D. Jecha, M.D., M.P.H

District Health Officer

Benton-Franklin District Health Dept.

$506 \mathrm{McKenzie} \mathrm{St.}$

Richland, WA 99352 
No. of

Copies

Z. Jackson, Chairman

Tribal Council

Confederated Tribes of the

Warm Springs Reservation

P.O. Box C

Warm Springs, OR 97761

M. Leifer, EH-222

Department of Energy

Forrestal Bldg. Room 3G-089

1000 Independence Ave.

Washington, D.C. 20585

K. J. Mahoney

BDM International, Inc.

7915 Jones Branch Drive

McLean, VA 22102-3396

R. Mathias, ER-70

Department of Energy

Room F-208

Germantown, MD 20545

T. D. McGee

Counsellor (Energy)

Canadian Embassy

1746 Massachusetts Ave. NW

Washington, D.C. 20036

M. McHugh

Colorado Department of Health

P.O. Box 7302

Crescent Branch Station

Golden, CO 80403

R. R. Mooney

Washington State Dept of

Social \& Health Services

LE-13

Olympia, WA 98504-0095
No. of

Copies

\section{N. Morin}

Rocky Flats Program Unit

Environmental Epidemiology Division

Colorado Dept. of Health

4210 E. 11 th Ave.

Denver, CO 80220

C. Morris, DP-3

Department of Energy

Forrestal Bldg. Room 4A-045

1000 Independence Ave.

Washington, D.C. 20585

J. D. Mulder

Public Health Liaison to EPA

U.S. EPA

1200 Sixth Ave.

Seattle, WA 98101

D. Nelson, EH-33

Department of Energy

Room G-144

Germantown, MD 20545

G. Nenema, Chairman

Kalispel Business Council

P.O. Box 39

Usk, WA 99180

D. Oliver, R.S., M.P.A.

Hazardous Waste Coordinator

Toxic Substances Section

Dept of Social \& Health Services

LD-11

Olympia, WA 98504

E. H. Patawa, Chairman

Board of Trustees

Confederated Tribes of the

Umatilla Indian Reservation

P.O. Box 638

Pendleton, OR 97801 
No. of

Copies

A. V. Pinkham, Chairman

Nez Perce Tribal Exec Committee

P.O. Box 305

Lapwai, ID 83540

W. J. Roberds

Golder Associates

4104 148th N.E.

Redmond, WA 98052

J. Ruttenber

Centers for Disease Control

2858 Woodcock Blvd.

Koger Center F-28

Atlanta, GA 30341

M. Sampson, Chairman

Tribal Council

Confederated Tribes and Bands of the Yakima Indian Nation

P.O. Box 151

Toppenish, WA 98948

M. Schulman, ER-70

Department of Energy

Room F-207

Germantown, MD 20545

G. Sherwood, NE-12

Department of Energy

Room E-478

Germantown, MD 20545

J. S. Smith

Bureau of Preventive Medicine

Idaho Dept. of Health \& Welfare 450 W. State Street

Boise, ID 83720

E. Stensgar, Chairman

Coeur d'Alene Tribal Council

Plummer, ID 83851
No. of

Copies

J. S. Stohr

Office of Nuclear Waste Mgmt

Department of Ecology

99 South Sound Center

Mail Stop PV-11

Olympia, WA 98504

J. Thomas, HEAL

325 S. Oak St.

Spokane, WA 99204

M. Tonasket, Chairman

Colville Business Council

P.O. Box 150

Nespelem, WA 99165

J. Tseng, EH-20

Department of Energy

Forrestal Bldg. Room 7A-075

1000 Independence Ave.

Washington, D.C. 20585

Stan Vendetter

Benton-Franklin District Health Dept. 506 McKenzie St.

Richland, WA 99352

A. Wallo, EH-232

Department of Energy

Forrestal Bldg. Room GA-076

1000 Independence Ave.

Washington, D.C. 20585

2 DOE Office of Scientific and

Technical Information

Technical Information Center

P.O. Box 62

Oak Ridge, TN 37830

\section{ONSITE}

1 Hanford Environmental Health

Foundation

S. E. Dietert

H1-03

Distr.4 
No. of

Copies

2 Westinghouse Hanford Company
C. D. Carpenter
D. E. Wood
H4-15
H4-5I

12 DOE Richland Operations

T. A. Bauman,COM

R. F. Brich, SEC (2)

R. A. Holten, SED

J. R. Hunter, OPD

J. J. Keating, AMS

J. E. Mecca, OPD

R. M. Rosselli, AMA

R. R. Tibbatts, FRD

M. W. Tiernan, SED (2)

M. J. Zamorski, OPD

A7-75

A5-55

A5-55

A6-55

A6-54

A6-55

A7-70

A7-88

A5-55

A6-55

43 Pacific Northwest Laboratory

D. L. Alamia

J. W. Brothers

D. S. Broussard

T. D. Chikalla

T. T. Claudson

P. M. Cleavenger

R. Cuello

P8-55

P7-50

K1-86

K1-74

K1-45
No. of

Copies
G. H. Cunningham
K1-59
J. W. Falco
K6-78
S. M. Finch
K6-89
R. O. Gilbert
K1-85
W. A. Glass
K1-40
R. H. Gray
K1-30
S. P. Gydesen
P8-55
G. L. Harvey
T. A. Ikenberry
K1-55
R. C. Liikala
K3-54
A. H. McMakin
K1-57
L. G. Morgan
B. A. Napier
K6-86
K2-35
T. A. Nelson
K3-54
R. E. Rhoads
K1-55
R. L. Skaggs
K6-64
R. G. Stevens
K6-77
W. L. Templeton
K6-45
K $1-30$
S. B. Yabusaski
K6-77
W. R. Wiley
$\mathrm{K} 1-46$
R. K. Woodruff (2)
K5-09
H. E. Wyer
K1-11
Project Office Files (5)
Public Reading Room (5)
K6-89
Records Center
A1-65
Technical Library (2)
K3-70
P8-55

Distr.5 
